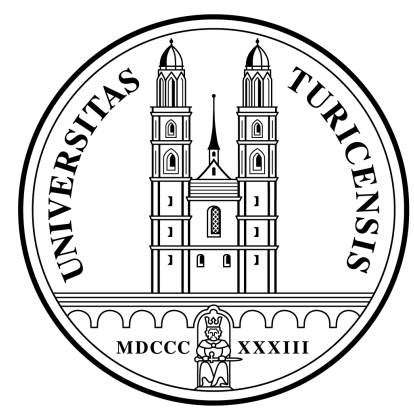

Institute for Empirical Research in Economics

University of Zurich

Working Paper Series

ISSN 1424-0459

Working Paper No. 104

Two Concerns about Rational Choice:

Indoctrination and Imperialism

Bruno S. Frey and Stephan Meier

January 2002 


\title{
Two Concerns About Rational Choice: Indoctrination and Imperialism
}

\author{
Evidence from a Natural Experiment
}

\author{
Bruno S. Frey* \\ Stephan Meier
}

Bruno S. Frey is Professor of Economics, and Stephan Meier is Research Assistant Institute for Empirical Economic Research, University of Zurich,

Bluemlisalpstrasse 10, 8006 Zurich, Switzerland

Tel.: 0041-1-634 37 28, Fax: 0041-1-634 49 07,

E-mail: bsfrey@iew.unizh.ch,smeier@iew.unizh.ch.

* Corresponding author. 


\title{
Two Concerns About Rational Choice: Indoctrination and Imperialism
}

\author{
Evidence from a Natural Experiment
}

(December 12, 2001)

\begin{abstract}
:
Rational Choice Theory is often criticized to indoctrinate students in a negative, which is supported by some laboratory experiments. But do students of Rational Choice Theory really behave more selfishly? This paper presents evidence from a natural decision on voluntary donation at the University of Zurich. The analysis of the very large panel data set reaches significant different results than previous studies: Rational Choice Theory does not indoctrinate students. However, there are good other reasons to criticize Rational Choice Theory. The paper argues that ideas from other social sciences should be imported to improve the theory. Three elements are presented which lead to new and different policy conclusions. (108 words)
\end{abstract}

JEL classification: A13, A20, H41

Keywords: Rational Choice, Public Goods, Giving Behavior, Education, Behavioral Economics 
Rational Choice theory has been criticized for many different reasons. ${ }^{1}$ This paper specifically addresses two concerns which prevail two different levels: The first concern argues that an indoctrination with Rational Choice thinking induces people to act more selfishly than they otherwise would. The theory can be accused of creating the type of selfish person it axiomatically assumes.

The second concern argues that Rational Choice theory, by assuming that people behave like selfish utility-maximizers, is based on a too narrow concept of a person. Crucial insights from other social sciences, in particular from social psychology, are disregarded. The critics postulate that Rational Choice theory should integrate such knowledge. Instead of being an imperial science, it should become an importer of insight.

These two concerns are well reflected in Elinor Ostrom's Presidential Address at the American Political Science Association conference in 1997, in which she advocates to develop a behavioral Rational Choice theory of collective action (Ostrom 1998). She argues that the scholarly achievements of a wide range of different disciplines should be incorporated into Rational Choice models in order to have a better understanding of human behavior. To introduce insights from other social sciences into the models, e.g. challenges the notion that the state always has to intervene in order to solve a social dilemma. Moreover, Ostrom sees another benefit of a behavioral Rational Choice model: it improves the civic education of our students. There, the argument about the concerns goes full circle or, to put it differently, the contemporary Rational Choice approach has a negative effect on the cooperative behavior of our students.

\footnotetext{
${ }^{1}$ See e.g. Green and Shapiro 1994 and the literature cited therein.
} 
"We are producing generations of cynical citizens with little trust in one another, much less in their government. Given the central role of trust in solving social dilemmas, we may be creating the very conditions that undermine our own democratic ways of life." (Ostrom 1998:18)

Other scholars have expressed similar criticism. They believe that training in economics theory negatively affects the behavior of the students. Students adjust their behavior to the economics theory taught rather than the other way round.

"Cynics are therefore in the business of making prophecies that threaten to become self-fulfilling. If the norm of public spirit dies, our society would look bleaker and our lives as individuals would be more impoverished. That is the tragedy of 'public choice'." (Kelman 1987:94)

But do we really have to be concerned about the effects of teaching Rational Choice theory? Interestingly enough, the empirical results available are mostly based on laboratory experiments are not uniform and thus do not all support the concern just raised. Moreover, experiments by economists with economics students have the problem that it cannot be excluded that the students just play the equilibrium they learned in their classes but behave quite differently in their every day life. We therefore here present empirical evidence from a natural experiment. The results do not support such an indoctrination hypothesis. Teaching Rational Choice theory does in fact not inhibit cooperation. The second part of our paper argues that there are nevertheless good reasons to refrain from further economic imperialism and to import ideas from other social sciences, above all psychology, into Rational Choice models.

The paper proceeds as follows. Section I summarizes previous research on the influence of economic theory on cooperation. The data set used is presented in Section II. The following Section interprets the results. Section IV discusses possibilities to enrich Rational Choice theory. The final section draws conclusions. 


\section{Previous Research}

An often cited paper about the effect of Rational Choice thinking on students' cooperation is by Frank, Gilovich and Regan $(1993,1996)$. They show in a prisoner's dilemma game and in a survey that economists are less cooperative and donate significantly less money to charities than other people. They find evidence that this lower readiness to cooperate is caused partly by economics education and that there is "... a heavy burden of proof on those who insist that economics training does not inhibit cooperation"(1996:192). Similar results are found by Blais and Young (1999) who test the impact of the Rational Choice model of voting on political participation in a national election in Canada. They replicate an idea of Brunk (1980) in a more sophisticated way. Their 10-12 minutes introduction to Downs' participation model (which argues that vote participation is irrational as the probability of changing the outcome is minimal) cet. par. reduced the turnout of the students involved by 7 percentage points. Hence, the exposure to the economic theory of voting is found to erode students' civic virtue. The answers to a questionnaire suggest that the exposure to Rational Choice theory changes not only the perceived probability of casting a decisive vote but also affects peoples' attitudes, such as acceptance of norms, perceived social pressure or perceived obligation to vote in a democracy.

But the literature on the topic is not uniform. Some studies do not find any behavioral differences between economists and non-economists (Isaacs et al. 1985; Laband and Beil 1999). Though other studies do find differences between economists and non-economists, they attribute these behavioral differences to a selection rather than to an indoctrination effect of economics training (e.g. Marwell and Ames 1981; Frey, Pommerehne and Gygi 1993; and Frank and Schulze 2000). Yezer, Goldfarb and Poppen (1996) even claim that economists are more cooperative than students of other majors. 
These inconsistent conclusions are mainly based on experimental evidence. But it is problematic to solely analyze the influence of economics training with experimental evidence. It cannot be excluded that students see the experimental setting 'as an IQ test of sorts' (Frank 1988: 226). Students with knowledge of Rational Choice theory may behave in the experiments the way they suppose or know theory suggests, while they act quite differently in ordinary life. The relevant question is not how people with knowledge of Rational Choice theory play in an experimental game but how they act in their normal life. Therefore, one should look at behavior in an actual setting. In the next section, we present our unique data set based on real life behavior.

\section{Data}

At the University of Zurich, all students are asked each semester by the University administration whether they want to contribute to two official funds - in addition to the compulsory tuition fee. Before the semester starts, the students must decide based on an official letter whether they want to donate money to needy students (CHF 7.-, about US\$ 4.20), who then can receive a free loan from one of the funds and/or if they want to donate money to foreign students (CHF 5.-, about US\$ 3), who can receive money in order to study for one or two semesters in Zurich. By ticking a respective box students consent to pay into the funds. We observe the decisions for the period between the winter semester 1998/99 up to and including the winter semester 2000/01 (i.e. five semesters). The fact that every student has to decide on his or her contribution each semester leads to a large number of observations. We can observe the giving behavior of 28'586 students who decide on average 3.4 times, depending on their number of semesters. With this data set, it is possible to test whether training in economic theory really erodes the willingness to cooperate, or more generally, civic virtue and trust. 
To test whether economic theory has a negative effect on the cooperative behavior of our students, we consider two groups of students who are exposed in different ways to economic theory: non-economists, who do not learn the special heuristic assumptions concerning human behavior, and economics students, who learn Rational Choice theory as part of their studies. The way the study of economics is organized at the University of Zurich allows us to control for different levels of economic knowledge. In a first stage, students undertake their basic study, which takes about 2 years ( 4 semesters). After passing an exam covering basic microeconomics, they enter the main stage and choose between political and business economics. After their graduation, students may start their Ph.D. study. The strict official procedure when asking the students about a contribution to the two funds offers a good environment for studying the question of whether students with knowledge in Rational Choice theory behave differently from those without such knowledge.

\section{Analysis and Results}

A look at the descriptive statistics shows that economists donate less than non-economists. While 68.7 percent of students with non-economic majors give money to at least one fund, only 61.8 percent of economists are willing to contribute to the funds. ${ }^{2}$ This behavioral difference can be due to two effects. (1) Selection hypothesis. Selfish persons study economics and Rational Choice theory. Behavioral differences exist already at the beginning of their studies before a single lecture in economics theory. (2) Indoctrination hypothesis. Rational Choice theory erodes the willingness to cooperate of the students. During their studies they become more selfish. Only the indoctrination hypothesis is relevant for the question of whether exposure to economic theory

\footnotetext{
${ }^{2}$ From all economists who contribute to at least one funds $54.87 \%$ donate to both of the funds, $4.14 \%$ only to the Foreigner Fund and $2.79 \%$ to the Loans Fund. For non-economists the distribution is $61.84 \%, 4.46 \%, 2.35 \%$.
} 
changes one's behavior. Support for this second hypothesis would be extremely problematic for a concept of economic imperialism and Rational Choice theory because it would - as a negative extern effect of this successful analytical approach - raise students' selfish behavior.

The two hypothesis will now be analyzed in turn.

\section{Selection effect}

Table 1 shows the results of a probit analysis to test for a selection effect. The dichotomous dependent variable equals 1 if the students contribute to at least one social fund, and equals 0 if they decide not to give any money. The model is estimated for a subsample of students, namely freshmen. These students have not attended any lecture in economic theory at University. Therefore, these differences in behavior cannot be due to an indoctrination effect. Overall, we control for pre-university knowledge in economics with a dummy variable, which equals 1 if the students have attended economics courses in high school and 0 otherwise. Further control variables are personal factors (age, gender and nationality) and a dummy variable for the period (semester/year) in question. As it is the case in probit analyses that the coefficients are not easy to interpret, we give the marginal effects in the third column, to indicate, how the probability of contributing is affected compared to the reference group.

\section{TABLE 1}

The results of the estimation suggest a selection effect. Students who study economics behave more selfishly than other students independent of their knowledge in Rational Choice theory. The probability that they donate to one of the social funds is c.p. 4.5 percentage points lower than for non-economists who constitute the reference group. Pre-university knowledge in economics decreases the probability of contributing by 3.2 percentage points. This can be due to either a 
selection or indoctrination effect. But it can be excluded that pre-university knowledge explains the selection effect found for the University freshmen.

The estimation in table 1 also controls for personal characteristics which may influence giving behavior and systematically correlate with studying economics, e.g. women tend to study less often economics and might differ in their giving behavior. Not controlling for gender could bias the effect of studying economics. The control variables show the following effects: Women tend to donate less money than men to the two social funds, as do foreigners compared to the Swiss (however, only the gender effect is statistically significant). Age has a positive effect on donating but this is scarcely statistically significant. In recent semesters (periods), students were more willing to give money to the two funds than in earlier periods, as indicated by the positive signs of the respective coefficients.

Since the two hypothesis are not mutually exclusive we will test in the next section if there is in addition an indoctrination effect.

\section{Indoctrination effect}

The indoctrination hypothesis is supported if the difference between the contribution of economists and non-economists widens during their respective studies. To test for the economic knowledge of the students we look at different stages in their studies. At the end of every stage they prove their abilities in an written exam.

\section{TABLE 2}

Table 2 shows the results of a conditional logit estimation with personal fixed effects to control for unobserved heterogeneity. The results do not support the indoctrination hypothesis. The learning of economics theory does not make students behave more selfishly in this natural 
setting. None of the interaction terms, which should indicate a potential training effect are statistically significant. ${ }^{3}$ Our results diverge from those studies which found an indoctrination effect in laboratory experiments. Rather, the differences between economists and non-economists in cooperative behavior are due to a selection effect whereby persons with specific social preferences tend to take up economics studies. Economists tend to have different value priorities. In a survey at the University of Zurich we asked students to declare their political orientation on a left/right spectrum (ranging from 1 to 8 ; with $8=$ furthers left). Mean of the 413 economists was 4.54 (s.d. 1.46) while for the 2773 non-economists it was 5.79 (s.d. 1.47). Economists differ in their political orientation significantly from non-economists. Similar results get Gandal and Roccas (2000) who analyze the personal value priorities of economists and find systematical differences to non-economist. However, the result cannot be explained by an effect of any observable training in economics.

Our real life data set suggest that, public choice does not make students behave more selfishly or crowd-out their civic virtue. Thus, we find no evidence that makes a reform of Rational Choice education urgent in order not to produce even more selfish persons. Nevertheless, there are other important reasons to reform Rational Choice and to improve the underlying assumptions about human behavior.

\section{Importing new ideas into Rational Choice}

'Economic Imperialism', or more generally Rational Choice theory, which builds on the selfinterest assumption, has had great success in many areas outside economics, examples being politics, history, law, the arts, or the family (e.g. Becker 1976, 1996, Stigler 1984, Frey 1999,

\footnotetext{
${ }^{3}$ For a more detailed analysis of this effect see Frey and Meier 2000.
} 
Lazear 2000). It has been warned that the application of the calculus of self-interest may run into decreasing marginal returns. We postulate that ideas from other social sciences should be imported into Rational Choice theory and economics (see e.g. Frey 2001, Throsby 2001 and Ostrom 1998). While this is unlikely to change the behavior of the students of Rational Choice, it leads to systematically different policy conclusions. Such a new orientation of Public Choice should take into account that (1) people do not always act rationally in the sense of following the von Neumann/Morgenstern axioms; (2) individuals do not always react to changes in relative prices according to the standard economic prediction; and (3) personal discourse is an important aspect of human behavior. This incorporation of psychological insights leads to 'Behavioral Public Choice Theory' (for a survey of behavioral economics see Mullainathan and Thaler 2000, Thaler 2000). The three aspects are now more fully discussed:

(1) People do not always act rationally and therefore deviate from expected utility maximization, which in Rational Choice analysis is the standard model to describe how people decide about future actions (Thaler 1987, Frey and Eichenberger 1989). Such anomalies have been identified in experiments, real life situations and even in markets with almost perfect competition: the stock market (for a survey of behavioral finance see Shleifer 2000). Introducing these anomalies into Public Choice analysis helps to explain different puzzles (Quattrone and Tversky 1988, Frey and Eichenberger 1991). For example, individuals do not make decisions in an absolute way but always with respect to some standards. This reference point may often be the status quo or past experience (Samuelson and Zeckhauser 1988).

But individuals realize that they are subject to such anomalies and create appropriate institutions. Hence, many political actions are driven by the acceptance of anomalies. Pension schemes, for example, are a result of people's control problem to discount appropriately (O'Donoghue and 
Rabin 1999, Laibson 1997). The creation of such rules and institutions supports the notion that we do not have to relinquish Rational Choice theory but should accept rationality in a broader sense.

(2) Standard Rational Choice theory suggests that people react systematically to changes in relative prices. The incentives set from outside motivate people to behave in a predictable way. The incentive based policies such as the polluters-pay principle, pay for performance or fines for failing to participate in policies are built on this assumption. But political economists know that there must be more than this extrinsic motivation to undertake a specific task. A lot of observable activities such as donating money (e.g. Andreoni 1990, 1998, Clotfelter 1997 and Weisbrod 1997), tax paying (e.g. Slemrod 1992, Andreoni, Erard and Feinstein 1998) and voting (e.g. Mueller 1997, Jones and Hudson 2000) can not be explained by standard rational choice theory. There is wide empirical evidence that people have an intrinsic motivation, where people perform an activity for its own sake because of reasons lying within their own persons. Moreover, there is a dynamic relationship between extrinsic and intrinsic motivation: Under identifiable conditions extrinsic incentives crowd-out intrinsic motivation. The effect is well known and supported in various experimental studies in social psychology (Lepper and Greene 1978 and Deci and Ryan 1985, Ryan, Koestner and Deci 1999) and was introduced into economics as 'Crowding Out' effect (Frey 1997, for a survey see Frey and Jegen 2001).

Introducing the concept of intrinsic motivation and its potential crowding out by extrinsic rewards changes policy implications. Frey and Oberholzer-Gee (1997) show that a monetary compensation offered for a NIMBY (Not-In-My-Backyard) - project in a Swiss community did not increase but decrease political acceptance. The intrinsic motivation to exhibit civic virtue by accepting the project was crowded out. Similarly, Frey and Goette (1999) find that payment for 
volunteers, also in the political realm, has ceteris paribus a negative effect on effort. Volunteers have substantial intrinsic motivation which is crowded out under specific conditions. These results suggest that the relative price effect does not always work in the expected way. One should carefully consider the effect on intrinsic motivation while implementing extrinsic incentives.

(3) Communication tends to be neglected in Rational Choice analysis. In classical Prisoner's Dilemma games, actors are artificially constrained not to speak to each other. ${ }^{4}$ But it is known from many experiments that communication strongly helps to form contracts to prevent free riding (Sally 1995, Ostrom et al. 1994).

In political decision-making, the citizens' discourse is of crucial importance (Bohnet and Frey 1994, Frey 1994). For Public Choice analysis to understand the influence of communication is extremely fruitful. Oberholzer-Gee and Kunreuther (2000) present a theory and empirical evidence about how public opinion, revealed in public discussions and in the polls, can influence the decision of politicians. They find that politicians support projects that their community publicly favors and vice versa. The more direct democratic a political system, the more important is discussion. The choice between alternatives is hence only one aspect of the decision mechanism; perhaps even more important is the process of verbal exchange which takes place before casting the vote in a referendum or initiative. ${ }^{5}$ According to the philosophical and sociological theories of Habermas (1983) and Apel (1990), such discourse not only improves

\footnotetext{
${ }^{4}$ Tullock (1999) refers to the artificial non-verbal Prisoner's Dilemma. In his experiment he allows for communication and gets a very high degree of cooperation. For a meta-analysis about non-binding pre-play communication raising cooperation in public goods settings see Sally (1995).

${ }^{5}$ Frey and Stutzer (2001) show empirically that people derive utility from the political process as such. This utility is independent of the outcome of the decision.
} 
citizens' perception and information, but may also shapes the normative evaluation of the problem at stake.

\section{Conclusion}

This paper shows in the context of a natural experiment at the University of Zurich that the teaching of economic theory does not reduce the cooperative behavior of the students. Students of economics behave more selfishly than students of other disciplines but these differences are due to a selection effect rather than an indoctrination effect. Already before they start their study, students of economics donate less to a social purpose. In contrast to what is often feared and claimed, the conventional Rational Choice approach does not reduce the civic virtue of the students analyzed. The students seem to understand that Rational Choice is not a normative advice for everyday life. Nevertheless, there are good reasons to change Rational Choice theory. Ideas from other social sciences should be imported to get a broader understanding of human behavior. The paper presents three elements bringing new insights into the analysis of political decision-making: decision anomalies, intrinsic motivation and personal discourse. They lead to significantly different policy conclusions and help to develop Rational Choice analysis in a fruitful way - but don't expect our students to become better human beings.

\section{References}

Andreoni, J., B. Erard and J. Feinstein (1998). Tax Compliance. Journal of Economic Literature 36. 818-860.

Andreoni, James (1990). Impure Altruism and Donations to Public Goods: A Theory of WarmGlow Giving. Economic Journal 100(401). 464-477.

Andreoni, James (1998). Toward a Theory of Charitable Fundraising. Journal of Political Economy 106. 1186-1213.

Apel. K.-O. (1990). Diskurs und Verantwortung: Das Problem des Übergangs zur postkonventionellen Moral. Frankfurt: Suhrkamp. 
Becker, Gary S. (1976). The economic approach to human behavior. Chicago/London: University of Chicago Press.

Becker, Gary S. (1996). The economic way of looking at behavior: the Nobel Lecture. Stanford University: Hoover Institution on War, Revolution and Peace.

Blais, André und Robert Young (1999). Why Do People Vote? An Experiment in Rationality. Public Choice 99. 39-55.

Bohnet, Iris and Bruno S. Frey (1994). Direct-Democratic Rules: The Role of Discussion. Kyklos 47. 341-354.

Brunk, Gregory G. (1980). The Impact of Rational Participation Models on Voting Attitudes. Public Choice 35. 549-564.

Clotfelter, Charles T. (1997). The Economics of Giving. In: Barry, John W. und Bruno V. Manno (Hrsg.). Giving Better, Giving Smarter. Washington, D.C.: National Commission on Philanthropy and Civic Renewal. 31-55.Clotfelter1997

Deci, Edward L. and Richard Ryan (1985). Intrinsic motivation and self-determination in human behavior. New York: Plenum.

Deci, Edward L., Richard Koestner and Richard Ryan (1999). A Meta-Analytic Review of Experiments Examining the Effects of Extrinsic Rewards on Intrinsic Motivation. Psychological Bulletin 125. 627-668.

Feld, Lars P. and Gebhard Kirchgässner (2000). Direct Democracy, Political Culture, and the Outcome of Economic Policy: Some Swiss Experience. European Journal of Political Economy 16. 287-306.

Frank, Björn und Günther G. Schulze (2000). Does Economics Make Citizens Corrupt?. Journal of Economic Behavior and Organization 43 (1). 101-113.

Frank, Robert H. (1988). Passions Within Reason. New York: W.W. Norton.

Frank, Robert H., Thomas Gilovich und Dennis T. Regan (1993). Does Studying Economics Inhibit Cooperation? Journal of Economic Perspectives 7 (2). 159-171.

Frank, Robert H., Thomas Gilovich und Dennis T. Regan (1996). Do Economists Make Bad Citizens? Journal of Economic Perspectives 10 (1). 187-192.

Frey, Bruno S. (1994). Direct Democracy: Politico-Economic Lessons from Swiss Experience. American Economic Review 84. 338-348.

Frey, Bruno S. (1999). Economics as a science of human behaviour: towards a new social science paradigm. Boston et al.: Kluwer Academic Publishers.

Frey, Bruno S. (2001). Inspiring Economics: Human Motivation in Political Economy. Cheltenham: Edward Elgar.

Frey, Bruno S. and Reiner Eichenberger (1989). Schould Social Scientists Care About Choice Anomalies? Rationality and Society 1. 101-122.

Frey, Bruno S. and Reiner Eichenberger (1991). Anomalies in Political Economy. Public Choice 68. 71-89. 
Frey, Bruno S. and Reto Jegen (2001). Motivation Crowding Theory: A Survey of Empirical Evidence. Journal of Economic Surveys 15(5). 589-611.

Frey, Bruno S. and Stephan Meier (2000). Political Economists Are Neither Selfish Nor Indoctrinated. University of Zurich, Institute for Empirical Research in Economics, Working Paper Series No. 69.

Frey, Bruno S., Werner W. Pommerehne und Beat Gygi (1993). Economics Indoctrination or Selection? Some Empirical Results. Journal of Economic Education 24 (3).

Gandal, Neil and Sonia Roccas (2000). Good Neighbors/Bad Citizens: Personal Values Priorities of Economists. Foerder Institute Working Paper.

Green, Donald P. and Ian Shapiro (1994). Pathologies of Rational Choice Theory: A Critique of Applications in Political Science. New Haven and London: Yale University Press.

Habermas, Jürgen (1983). Diskursethik - Notizen zu einem Begründungsprozess. In: Jürgen Habermas (ed.). Moralbewusstsein und kommunikatives Handeln. Frankfurt: Suhrkamp. 53125.

Isaac, R. Mark, Kenneth F. McClue und Charles R. Plott (1985). Public Goods Provision in an Experimental Environment. Journal of Public Economics 26. 51-74.

Jones, Philip and John Hudson (2000). Civic Duty and Expressive Voting: Is Virtue its Own Reward? Kyklos 53 (1): 3-16.

Kelman, Steven (1987). "Public Choice" and Public Spirit. The Public Interest 87 (Spring). 8094.

Laband, David N. und Richard Beil (1999). Are Economists More Selfish Than Other 'Social' Scientists? Public Choice 100. 85-100.

Laibson, David (1999). Golden Eggs and Hyperbolic Discounting. The Quarterly Journal of Economics 112 (2). 443-477.

Lazear, Edward P. (2000). Economic Imperialism. Quarterly Journal of Economics 115 (1). 99146.

Lepper, M., \& Greene, D. (1978). The Hidden Cost of Rewards. Hillsdale, N.J.: Erlbaum.

Marwell Gerald und Ruth E. Ames (1981). Economists Free Ride, Does Anyone Else?

Experiments on the Provision of Public Goods IV. Journal of Public Economics 15. 295-310.

Mueller, Dennis C. (ed.) (1997). Perspectives on Public Choice. Cambridge: Cambridge University Press.

Mullainathan, Sendhil and Richard H. Thaler (2000). Behavioral Economics. Massachusetts Institute of Technology, Department of Economics, Working Paper Series.

O’Donoghue, Ted and Matthew Rabin (1999). Doing It Now Or Later. American Economic Review 89(1). 103-124.

Oberholzer-Gee, Felix and Howard Kunreuther (2000). Decision-Making Under Social Pressure: The Political Economy of Debating Socially Sensitive Issues. Wharton School. University of Pennsylvania. 
Ostrom, Elinor (1998). A Behavioral Approach to the Rational Choice Theory of Collective Action. Presidential Address, American Political Science Association 1997. American Political Science Review 92 (1). 1-22.

Ostrom, Elinor, R. Gardner and J. Walker (1994). Rules, Games, and Common-Pool Resources. University of Michigan Press, Ann Arbor.

Quattrone, G.A. and A. Tversky (1988). Contrasting Rational and Psychological Analysis of Political Choice. American Political Science Review 82 (3). 719-736.

Sally, David (1995). Conversation and Cooperation in Social Dilemmas. Rationality and Society 7(1). 58-92.

Samuelson, W. and R. Zeckhauser (1988). Status quo bias in decision making. Journal of Risk and Uncertainty 1 (1). 1-53.

Shleifer, Andrei (2000). Inefficient Markets: An Introduction to Behavioral Finance. Claredon Lectures. Oxford University Press.

Slemrod, Joel (ed.) (1992). Why People Pay Taxes. Tax Compliance and Enforcement. Ann Arbor: University of Michigan Press.

Stigler, George J. (1984). Economics - The Imperial Science? Scandinavian Journal of Economics 86. 301-313.

Thaler, Richard (1987). The Psychology of Choice and the Assumptions of Economics. In: A.E. Roth. Laboratory Experimentation in Economics. Cambridge: Cambridge University Press. 99-130.

Thaler, Richard (2000). From Homo Economicus to Homo Sapiens. Journal of Economic Perspectives 14(1). 133-141.

Throsby, David (2001) Economics and Culture. Cambridge: Cambridge University Press.

Tullock, Gordon (1999). Non-Prisoner's Dilemma. Journal of Economic Behavior and Organization 39. 455-458.

Weisbrod 1997

Yezer, Anthony M., Robert S. Goldfarb und Paul J. Poppen (1996). Does Studying Economics

Discourage Cooperation? Watch What We Do, Not What We Say or How We Play. Journal of Economic Perspectives 10 (1). 177-186. 


\section{Table 1}

\section{Contribution of Economists and Non-Economists in the first semester}

University of Zurich 1998-2000

Dichotomous dependent variable: 'Contribution to at least one fund' $=1$

Probit estimates

\begin{tabular}{lllc}
\hline \hline Variable & \multicolumn{1}{c}{ Coefficient } & Z-value & Marginal effect \\
\hline Economist (1 = economist) & $-0.137^{* *}$ & -2.824 & $-4.5 \%$ \\
& & & \\
Pre-university knowledge & $-0.096^{*}$ & -2.538 & $-3.2 \%$ \\
& & & \\
Control variables & & & \\
Gender (female=1) & & & $-2.7 \%$ \\
Nationality (foreigner=1) & $-0.083^{* *}$ & -2.637 & $-1.3 \%$ \\
Age 26-30 & 0.039 & -0.658 & $0.2 \%$ \\
Age 31-35 & 0.060 & 0.084 & $2.0 \%$ \\
Age 36-40 & 0.283 & 0.548 & $9.3 \%$ \\
Aged over 40 & $0.375^{*}$ & 2.214 & $12.4 \%$ \\
Period 2 (summer semester 1999) & 0.167 & 1.491 & $5.5 \%$ \\
Period 3 & $0.381 * *$ & 10.108 & $12.6 \%$ \\
Period 4 & 0.157 & 1.378 & $5.2 \%$ \\
Period 5 & $0.394^{* *}$ & 10.330 & $13.0 \%$ \\
Constant & $0.421 * *$ & 12.559 & \\
\hline N & -4495.5528 & & \\
Log Likelihood & 7749 & & \\
\hline \hline
\end{tabular}

Notes: $\quad$ Reference group consists of 'non-economists', 'without pre-university economic knowledge', 'aged below 26', 'male', 'Swiss', 'semester 1998/99'.

Level of significance: $* 0.01<\mathrm{p}<0.05, * * \mathrm{p}<0.01$

Data source: Compiled from data provided by the accounting department of the University of Zurich. 
Table 2

\section{Contribution of Economists and Non-Economists}

University of Zurich 1998-2000

Dichotomous dependent variable: 'Contribution to at least one fund' $=1$

Conditional fixed effects logit model

\begin{tabular}{lcc}
\hline \hline Variables & Coefficient & Z-value \\
\hline & & \\
Freshmen & $-0.440^{* *}$ & -7.431 \\
Freshman*Economist & $0.424^{* *}$ & 2.745 \\
& & \\
Main stage & -0.146 & -1.615 \\
Main stage*Economist & 0.340 & 1.446 \\
& & \\
Ph.D. & -0.272 & -1.825 \\
Ph.D. Economist & 0.338 & 0.493 \\
& & \\
Age & $0.111^{* *}$ & 2.415 \\
Number of semesters & -0.037 & -1.489 \\
& & \\
\hline N & & \\
Log Likelihood & 29,874 & \\
LR chi & & \\
\hline \hline
\end{tabular}

Notes: Reference group consists of 'non-economists', 'basic study'.

Level of significance: $* 0.01<\mathrm{p}<0.05, * * \mathrm{p}<0.01$

Data source: Compiled from data provided by the accounting department of the

University of Zurich. 